\title{
Genome-wide patterns of genetic diversity, population structure and demographic history in mānuka (Leptospermum scoparium) growing on indigenous Māori land
}

\author{
Emily Koot ${ }^{1}$, Elise Arnst ${ }^{2}$, Melissa Taane ${ }^{1}$, Kelsey Goldsmith $^{3}$, Amali Thrimawithana ${ }^{4}$, \\ Kiri Reihana ${ }^{2}$, Santiago C. González-Martínez ${ }^{5}$, Victor Goldsmith ${ }^{3}$, Gary Houliston ${ }^{6}$, and \\ David Chagné ${ }^{1}$ \\ ${ }^{1}$ Plant and Food Research Palmerston North \\ ${ }^{2}$ Manaaki Whenua \\ ${ }^{3}$ Kaiaka Consulting Limited \\ ${ }^{4}$ Plant and Food Research Ltd \\ ${ }^{5}$ INRAE \\ ${ }^{6}$ Landcare Research New Zealand
}

July 20, 2021

\begin{abstract}
Leptospermum scoparium J. R. Forst et G. Forst, known as mānuka by Māori, the indigenous people of Aotearoa (New Zealand), is a culturally and economically significant shrub species, native to New Zealand and Australia. Chemical, morphological and phylogenetic studies have indicated geographical variation of mānuka across its range in New Zealand, and genetic differentiation between New Zealand and Australia. We used pooled whole genome re-sequencing of 76 L. scoparium and outgroup populations from New Zealand and Australia to compile a dataset totalling $\sim 2.5$ million SNPs. We explored the genetic structure and relatedness of L. scoparium across New Zealand, and between populations in New Zealand and Australia, as well as the complex demographic history of this species. Our population genomic investigation suggests there are five geographically distinct mānuka gene pools within New Zealand, with evidence of gene flow occurring between these pools. Demographic modelling suggests three of these gene pools have undergone expansion events, whilst the evolutionary histories of the remaining two have been subjected to contractions. Furthermore, mānuka populations in New Zealand are genetically distinct from populations in Australia, with coalescent modelling suggesting these two clades diverged $\sim 9-12$ million years ago. We discuss the evolutionary history of this species and the benefits of using pool-seq for such studies. Our research will support the management and conservation of mānuka by landowners, particularly Māori, and the development of a provenance story for the branding of mānuka based products.
\end{abstract}

\section{Hosted file}

Manuka manuscript Authorea.pdf available at https://authorea.com/users/344633/articles/ 519143-genome-wide-patterns-of-genetic-diversity-population-structure-and-demographichistory-in-m\%C4\%81nuka-leptospermum-scoparium-growing-on-indigenous-m\%C4\%81ori-land 